\title{
PENDIDIKAN DAN KEARIFAN LOKAL ERA PERSPEKTIF GLOBAL
}

\author{
Agus Susilo, Yadri Irwansyah \\ Dosen Pendidikan Sejarah STKIP PGRI Lubuklinggau \\ Alamat korespondensi: Agussusilo594@yahoo.co.id
}

Diterima: 6 Desember 2018; Direvisi: 18 Januari 2019; Disetujui: 20 Januari 2019

\begin{abstract}
Education and local wisdom in the era of global perspective is how the role of a teacher in guiding students without leaving the values of local wisdom in the community. A teacher is a change actor who is able to make students better, more advanced in thinking and have a wise nature. The teacher is basically an education fighter who continues to devote his knowledge to the progress of a nation through the world of education. In this case the teacher must also understand the environment in his community. The values of local wisdom that are often forgotten, continue to be taught by a teacher so as not to forget. The community has a broad role in helping the world of education in introducing local wisdom in the lives of their students. It is hoped that the young generation that will be produced will be the younger generation who are ready to compete in the world order of the era of 4.0. The Ulak Lebar site which is a local site for the people of Lubuklinggau City which has a very high characteristic of the local community of the city of Lubuklinggau. The remaining and well-maintained evidence will be the subject of study of Local History. In school learning, especially history lessons, the introduction of local history in Lubuklinggau City should be actualized to students. The value in the Ulak Lebar Site will be the identity of the people of Lubuklinggau City who are rich in the values of the nation's character with global insight.
\end{abstract}

Keywords: Education; Local Wisdom; Global Perspective

\section{Abstrak}

Pendidikan dan kearifan lokal era perspektif global adalah bagaimana peran seorang guru dalam membimbing peserta didik tanpa meninggalkan nilai-nilai kearifan lokal yang ada dalam masyarakat. Seorang guru merupakan pelaku perubahan yang mampu membuat peserta didik lebih baik, lebih maju dalam pemikiran dan mempunyai sifat yang bijaksana. Guru pada dasarnya adalah seorang pejuang pendidikan yang terus mengabdikan ilmunya demi kemajuan sebuah bangsa melalui dunia pendidikan. Dalam hal ini guru juga harus memahami lingkungan dalam masyarakatnya. Nilai-nilai kearifan lokal yang seringkali dilupakan, terus diajarkan oleh seorang guru agar tidak lupa. Masyarakat memiliki peran yang luas dalam membantu dunia pendidikan dalam mengenalkan kearifan lokal dalam hidup anak didiknya. Diharapkan generasi muda yang dihasilkan kelak adalah generasi muda yang siap bersaing dalam tatanan dunia era 4.0. Situs Ulak Lebar yang merupakan situs lokal masyarakat Kota Lubuklinggau yang memiliki ciri khas masyarakat lokal kota Lubuklinggau yang sangat tinggi. Bukti-bukti peninggalannya yang masih ada dan terawat dengan baik akan menjadi bahan kajian Sejarah Lokal. Dalam pembelajaran di Sekolah, khususnya pelajaran sejarah, sudah seharusnya pengenalan sejarah lokal di Kota Lubuklinggau diaktualisasikan ke pada siswanya. Nilai yang ada dalam Situs Ulak Lebar akan menjadi identitas masyarakat Kota Lubuklinggau yang kaya akan nilai karakter bangsa berwawasan global.

Kata Kunci: Pendidikan; Kearifan Lokal; Perspektif Global

\section{A. Pendahuluan}

Latar belakang penelitia Pada dewasa ini, pendidikan merupakan suatu hal yang sangat penting, setiap orang berhak mendapatkan pendidikan. Pendidikan seperti suatu kebutuhan pokok yang urgensinya harus dipenuhi di era yang semakin modern ini.
Pendidikan pada zaman sekarang bukanlah sesuatu yang langka atau sifatnya yang terbatas untuk kalangan tertentu, karena Pemerintah sudah menyediakan berbagai fasilitas baik dari segi sarana prasarana maupun beasiswa bagi masyarakat yang kurang mampu secara finansial. Dalam meningkatkan 
mutu pendidikan, pemerintah telah dan sedang mengadakan pengembangan yang meliputi segi fisik dan non fisik (Sanjaya, Wina, 2016: 4).

Pembelajaran pada dasarnya sebuah proses untuk menata kehidupan yang lebih baik dan teratur. Belajar diperlukan oleh individu manusia akan tetapi belajar juga harus dipahami sebagai sesuatu kegiatan dalam mencari dan membuktikan kebenaran. Dalam praktek proses belajar atau pembelajaran akan menghasilkan suatu kondisi di mana individu dalam hal ini siswa dan guru, siswa dengan siswa atau interaksi yang kompleks yang akan ditemukan suatu proses komunikasi. Landasan sosiologis ini sangat penting dalam mengiringi perkembangan inovasi pembelajaran yang banyak terimbas oleh perubahan zaman yang semakin hedonistik. Maka pemahaman akan belajar yang ditinjau dari aspek sosiologis inilah yang sangat dibutuhkan dewasa ini (Daryanto \& Rahardjo, Muljo, 2012: 17-18).

Arus globalisasi, modernisasi dan ketatnya puritanisme dikhawatirkan dapat mengakibatkan terkikisnya rasa kecintaan terhadap budaya lokal. Sehingga kebudayaan lokal yang merupakan warisan leluhur terlupakan oleh budaya asing, tereliminasi di kandangnya sendiri dan seakan tidak dipedulikan oleh para pewarisnya. Mereka cenderung lebih bangga dengan karya-karya asing, dan gaya hidup yang ke Barat-Baratan dibandingkan dengan kebudayaan lokal di daerah mereka. Di dalam jati diri terkandung kearifan lokal (local wisdow) yang merupakan dari berbagai suku bangsa, kearifan lokal inilah harusnya dirajut dalam satu kesatuan kebudayaan (culture) untuk mewujudkan suatu bangsa, yaitu Bangsa Indonesia. Dalam pergiliran budaya antar generasi ini dibutuhkan adanya generasi perantara yang sudah mampu melakukan pemahaman dari generasi tua dan mampu mengkomunikasikan ke dalam bahasa yang ringan dan mudah dimengerti oleh generasi selanjutnya (Nadlir, 2014: 1-3).

Saat ini mutu guru di tanah air dipandang sangat rendah baik dari kompetensi pedagogis maupun kompetensi keilmuannya. Pada masa lalu, yaitu masa penjajahan dan pasca kemerdekaan sampai tahun 1960-an, mutu guru relatif baik. Banyak faktor yang menyebabkan rendahnya mutu guru ini. Diantaranya seperti mereka yang memasuki lembaga pendidikan guru pada umumnya bukanlah mereka yang memiliki jabatan guru sebagai pilihan pertama, melainkan karena banyak di antara mereka yang memasuki pendidikan guru disebabkan takut tidak diterima dan/ atau tidak diterima di lembaga pendidikan lainnya (Suyatno, dkk, 2009: 357).

Sebagai wahana utama dalam pembangunan bangsa dan watak (nation and charakter building), pendidikan dituntut untuk memberikan perhatian yang sungguh-sungguh terhadap pengembangan diri manusia Indonesia dalam keseluruhan dimensinya. Dimensi yang dimaksud adalah sejalan dengan hakikat kodrat manusia, yaitu manusia sebagai makhluk monodualis, dilihat dari aspek susunan kodrat (makhluk berjiwa-raga), bersifat kodrat (makhluk individu/berpribadi dan makhluk sosial), kedudukan kodrat (makhluk otonom/mandiri dan sekaligus makhluk ber-Tuhan). Perspektif membangun pendidikan sudah seyogyanya dilakukan dengan penuh keseriusan dalam mengembangkan inovasi dalam dunia pendidikan di era globalisasi saat ini 
(Rukiyati \& Purwastuti, L. Andriani, 2016: 131).

Ilmu pendidikan berkembang dengan pesat yang disertai kemajuan teknologi digital berdampak besar terhadap segala bidang, termasuk pendidikan. Dampak kemajuan teknologi digital yang semakin pesat tersebut juga berpengaruh terhadap pendidikan dan pembelajaran yang cepat karena kemunculan teknologi digital dan jaringan global. Untuk itu, teknologi pembelajaran mengadopsi dan mengadaptasikan temuan mutakhir ini dalam proses belajar. Teknologi pembelajaran bertujuan untuk memacu dan memicu proses belajar. Melalui sumber yang tepat, teknologi pembelajaran memacu proses belajar seseorang menjadi lebih cepat, lebih ringkas, serta mudah diakses. Belajar dalam teknologi pembelajaran dapat diselenggarakan melalui beragam pendekatan. Asas komunikasi masih dominan dalam menentukan proses belajar seseorang. Peranan media pembelajaran dan pemanfaatan sumber belajar kembali menjadi bukti yang jelas (Prawiradiliga, Dewi Salma, 2012: 48).

Pendidikan karakter sangat penting dalam mengembangan karakteristik anak dalam menjalankan kehidupannya didunia pendidikan dan masyarakat. Namun seorang guru tetap tidak boleh lepas tangan dalam membimbing anak untuk tetap mengenal karekteristik anak tersebut. Sebagaimana pentingnya karakter itu dalam dunia yang akan datang. Kearifan lokal sangat diperlukan dalam pendidikan, karena mengandung nilai-nilai kebaikan yang abadi dalam hubungannya dengan relasi keluarga, tetangga dan masyarakat lain. Peran kearifan lokal secara kritis mengubah dan membentuk budaya lokal menjadi bermakna dan sesuai dengan kehidupan sosial dan budaya masyarakat (Ghufronudin, dkk, 2017: 31).

Menurut Wahab dalam (Rukiyati \& Purwastuti, L. Andriani, 2016: 132), yaitu masyarakat pendukung nilai-nilai budaya dan beberapa diantaranya dapat dikategorikan sebagai local genius atau local knowledge dapat menjadi sumber nilai bagi masyarakat pendukungnya. Nilai-nilai budaya yang sudah dianggap baik berupa kearifan lokal dijadikan materi atau sumber materi pelajaran. Pendidikan karakter untuk anak usia Sekolah dasar ditekankan untuk mengunakan konsep pembelajaran tematik-integratif dalam praktiknya.

Berdasarkan fenomena pendidikan di Indonesia yang sudah dipaparkan diatas, hal tersebut mendorong penulis untuk memberikan suatu inovasi yang dapat memberi dampak positif bagi sistem pendidikan di Indonesia yakni Pendidikan Berbasis Nilai-Nilai Kearifan Lokal Dalam Perspektif Global.

\section{B. Metode Penelitian}

Sistematika Metode dalam penulisan ini adalah metode penelitian kualitatif yaitu suatu penelitian yang dilakukan didasarkan pada mutu dan kualitas yang terkandung didalamnya. Metode penelitian kualitatif ini berlandaskan pada filsafat pos postivisme. Metode ini juga disebut metode artistic, karena proses penelitian lebih bersifat seni (kurang terpola), dan disebut juga sebagai metode interpretive karena data hasil penelitian lebih berkenaan denagn interpretasi terhadap data yang ditemukan di lapangan. Metode penelitian kualitatif sering disebut metode penelitian naturalistik karena penelitiannya dilakukan pada kondisi yang alamiah (natural setting) disebut sebagai metode kualitatif, karena data yang terkumpul dan analisisnya lebih bersifat kualitatif. 
Objek ilmiah atau alamiah adalah objek yang berkembang apa adanya, tidak dimanipulasi oleh peneliti dan kehadirannya tidak mempengaruhi dinamika objek tersebut (Sugiyono, 2015: 2).

Dasar filosofis dari penelitian kualitatif sekurang-kurangnya ada empat dasar filosofis yang berpengaruh dalam penelitian kualitatif, yaitu sebagai berikut (Arikunto, 2002: 12-13) :

a. Fenomenologis, yang berpendapat bahwa kebenaran sesuatu itu dapat diperoleh dengan cara menangkap fenomena atau gejala yang memancar dari objek yang diteliti. Apabila peneliti melakukan penangkapan secara profesional, maksimal, dan bertanggung jawab maka akan dapat diperoleh variasi refleksi dari objek. Bagi objek manusia, gejala dapat berupa mimik, pantomimik, ucapan, tingkah laku, perbuatan, dan lain-lain.

b. Interaksi simbolik, yang merupakan dasar kajian sosial yang sangat berpengaruh dan digunakan dalam penelitian kualitatif. Beberapa ahli yang terkenal antara lain John Dewey dan Blumer H. Ahli yang kedua ini telah menyempurnakan pandangan interaksi simbolik dengan membagi tiga prinsip arti simbol yang diberikan oleh responden. Ketiga prinsip atau premis dimaksud adalah berikut ini :

c. Dasar manusia bertindak adalah untuk memenuhi kepentingannya. Dalam memberikan interpretasi tindakan atau fenomena, peneliti perlu sekali mengetahui proses atau sekuensi dari tindakannya. d. Proses suatu tindakan seseorang pada prinsipnya merupakan produk atau hasil proses sosial ketika orang tersebut berinteraksi dengan orang lain. Dalam memberikan interpretasi gejala, peneliti harus tepat mempertimbangkan hasil interaksi yang mempengaruhinya.

e. Manusia bertindak dipengaruhi oleh fenomena lain yang muncul lebih dulu atau bersamaan. Oleh karena itu peneliti perlu memperhatikan fenomena atau gejala yang berkaitan dan mempengaruhi munculnya gejala tersebut.

f. Kebudayaan sebagai sesuatu uyang merupakan hasil budi daya manusia yang mewujud dalam tingkah laku atau benda, bahasa, simbol, dan lain-lain. Kebudayaan tersebut melingkungi manusia hingga berpengaruh terhadap perilaku dan tindakan manusia. Oleh karena itu jika peneliti ingin memperoleh data yang akurat dan rinci perlu sekali mempelajari latar belakang kebudayaan responden, dan lebih baik lagi jika sanggup meluangkan waktu hidup bersama mereka beberapa lama.

g. Antropologi yaitu dasar filosofis yang fokus pembahasannya berkaitan erat dengan kegiatan manusia, baik secara normatif maupun historis. Itulah sebabnya peneliti perlu sekali peduli terhadap tindakan manusia di masa lalu dan kelanjutannya. Untuk menghasilkan gambaran yang tepat tentang fenomena antropologis peneliti menggunakan pendekatan 
induktif, dalam lingkup yang tidak terlalu luas, fleksibel, dan kontekstual. Dengan demikian peneliti dapat mendiskripsikan data secara tuntas berbentuk thick description, atas dasar fenomena yang ia jumpai di lapangan. Perumpamaan yang sederhana bagi data penelitian kualitatif adalah bahwa data tersebut berlapis-lapis seperti "umbi bawang". Peneliti mengupas lapisan umbi satu persatu untuk ditarik sebuah interpretasi yang komprehensif dan solid.

\section{Teknik Pengumpulan Data}

Teknik pengumpulan data yang digunakan dalam penelitian ini adalah teknik pustaka (library research), simak dan catat. Sebagai instrumen utamanya adalah peneliti sendiri, dalam hal ini peneliti akan membaca buku yang berkaitan dengan dunia pendidikan di era modern dan juga buku-buku yang berkaitan dengan kearifan lokal serta tidak lupa peneliti mengaitkan dengan peninggalan sejarah lokal yang memiliki nilai kearifan lokal dengan cermat dan menyesuaikan dengan tujuan penelitian. Adapun langkah-langkah pengumpulan data penelitian, penulis mengacu pada pendapat Rafiek (2013: 4), yaitu (1) Membaca buku pendidikan terkait pendidikan era globalisasi, Menguasai teori, (3) Menguasai metode, (4) Mencari data dan menemukan data, (5) Menganalisis data yang ditemukan secara mendalam, (6) Melakukan perbaikan secara menyeluruh,

Membuat simpulan penelitian.

\section{Teknik Analisis Data}

Pendekatan kualitatif merupakan data yang berwujud kata-kata dan bukan rangkaian kata serta dimulai dari fakta, realita, gejala, dan masalah yang diperoleh. Dalam menganalisis data, peneliti akan melakukan analisis data di lapangan. Salah satu analisis data di lapangan yang akan dipakai yaitu analisis data dari Miles and Huberman, yang telah dikutip oleh Sugiyono (2013). Dalam penelitian ini penulis menggunakan analisis data kualitatif, yaitu dengan melakukan sintesis secara langsung terhadap metode dalam artikel penelitian ini melalui proses, yaitu: (1) Data reduction, yaitu penulis memilih dan memilah-milah data yang akan dianalisis berupa kata, kalimat, atau ungkapan sesuai dengan metode penelitian kualitatif, yaitu metode langsung dan metode tidak langsung; (2) Data display, yaitu penulis menampilkan data yang telah dipilih dan dipilah-pilah dan menganalisis jenis metode penelitiannya; (3) Verification, yaitu penulis menyimpulkan hasil analisis terhadap penggunaan metode penelitian kualitatif yang dipakai (Muchtar, 2013: 135).

\section{Pembahasan}

\section{Pendidikan Berbasis Kearifan Lokal Dalam Perspektif Global}

Mutu pendidikan dengan sendirinya akan tercermin dari mutu sumber daya manusia, dimana sumber daya manusia kita pada umumnya masih rendah, berarti mutu pendidikan saat ini mayoritas masih rendah. Pemahaman tentang perilaku siswa dalam proses belajar merupakan yang sangat penting terutama bagi guru. Ada kecenderungan saat ini untuk kembali pada pemikiran bahwa anak akan lebih baik jika lingkungan diciptakan alamiah. Belajar akan lebih bermakna jika anak mengalami apa yang dipelajarinya, bukan mengetahuinya. Pembelajaran berorientasi pada penguasaan materi yang bertujuan memotivasi siswa untuk memahami makna materi pelajaran yang dipelajarinya dengan mengaitkan 
materi tersebut dengan konnteks kehidupan mereka sehari-hari (konteks pribadi, sosial, dan kultural) sehingga siswa memiliki pengetahuan/keterampilan yang secara fleksibel dapat diterapkan (ditransfer) dari satu permasalahan/konteks ke permasalahan/konteks lainnya (Daryanto \& Rahardjo, Muljo, 2012: 156).

Guru tidak dapat menanamkan nilai, memberikan pengetahuan dan menyebarkan kebijaksanaan dalam diri siswa kalau ia sendiri berhenti belajar. Situasi kerja guru yang telah menghabiskan waktu untuk kegiatan rutin tidak memngkinkan guru menambah informasi untuk membaca buku yang relevan dengan pengajarannya, atau merefleksikan hakikat perubahan nilai yang terjadi dalam masyarakat. Guru menjadi pendidik karakter karena ia memberikan diri dan hidupnya secara total kepada para siswanya. Ia memberikan ilmu pengetahuan yang dimilikinya, ia menawarkan nilai-nilai, kekayaan rohani, keprihatinan, kegembiraan, kegairahan, dan lain-lain, yang dimilikinya kepada para siswa. Guru mengajar dan mendidik membaktikan profesinya untuk mengubah dirinya sendiri dan hidup orang lain. Sebab apa hakikat pendidikan karakter, yaitu mengubah individu agar tumbuh menjadi manusia yang semakin utuh. Melalui ajaran dan didikannya guru mengubah anak didiknya menjadi manusia yang berkembang dan tumbuh sebagai manusia secara utuh dan semakin baik, mengantar mereka ke sebuah masa depan yang penuh tantangan agar mereka dapat terlibat secara aktif membentuk dan menata masyarakat menjadi lebih baik (Koesoema A, Doni, 2015: 148).
Arti nilai itu sendiri yaitu sesuatu yang memiliki nilai guna (memiliki keindahan), kebenaran atau kebaikan (Chotib, 2006: 153). Nilai juga memiliki arti lain yaitu kumpulan sikap atau perasaan atau anggapan tentang sesuatu hal mengenai baik atau buruk,benar atau salah, patut atau tidak patut, mulia atau hina, dan penting atau tidak penting. Nilai juga dianggap sebagai sesuatu yang selalu diinginkan, dicitacitakan, dan dianggap penting oleh seluruh manusia sebagai anggota masyarakat.

Kearifan itu sendiri merujuk pada sebuah nilai universal tentang keadilan sosial, kesejahteraan masyarakat dan kelestraian sumberdaya penghidupan masyarakat yang melandasi pola hubungan antar warga maupun dengan komunitas yang lain. Tidak disebut kearifan bilamana yang terjadi adalah sebuah ketidakadilan, kemiskinan, kelaparan, kerusakan ekositem dan penindasan (Widjajaputra, 2008: 2-3). Dengan demikian hal tersebut menjadi sangat penting untuk meninjau kembali keberadaan sistem lokal serta dinamika perubahannya untuk dapat dikatakan sebagai suatu kearifan (Haris, 2010).

Kearifan Lokal terdapat dalam semua aspek kehidupan karena berasal dari unsur budaya yang ada pada suatu daerah tertentu. Oleh karena itu, kearifan lokal dapat digunakan sebagai solusi alternatif dalam menangani permasalahan kehidupan. Kearifan lokal yang berasal dari unsur budaya daerah yang memiliki kemampuan untuk bertahan hidup, yaitu (1) mampu bertahan terhadap budaya luar, (2) memiliki kemampuan mengakomodasi unsur-unsur budaya luar, (3) mempunyai kemampuan mengintegrasikan unsur budaya luar ke dalam budaya asli, (4) mempunyai kemampuan mengendalikan, dan (5) 
mampu memberi arah pada perkembangan budaya (Anggrayni, Novi Trisna, 2013: 4).

Kuntoro (2012: 6), mengatakan bahwa kearifan lokal digunakan untuk mengindikasikan adanya suatu konsep bahwa dalam kehidupan sosial-budaya lokal terdapat suatu keluhuran, ketinggian nilai-nilai, kebenaran, kebaikan dan keindahan yang dihargai oleh warga masyarakat sehingga digunakan sebagai panduan atau pedoman untuk membangun pola hubungan di antara warga atau sebagai dasar untuk membangun pola hubungan di antara warga atau sebagai dasar untuk membangun tujuan hidup mereka yang ingin direalisasikan. Nilainilai kearifan lokal dapat dijadikan sebagai basis bagi pendidikan karakter di Sekolah. Harapan dari sebuah kearifan lokal yang tertuang dalam pendidikan karakter akan memperkokoh rasa kecintaan terhadap budaya bangsa sendiri ditengah maraknya budaya Barat yang berkembang pada saat ini. Pendidikan berbasis kearifan lokal atau keunggulan lokal dapat terlaksana dengan memanfaatkan keunggulan lokal dan global dalam aspek ekonomi, seni budaya, sumber daya manusia, bahasa, teknologi informasi dan komunikasi ke dalam kurikulum Sekolah yang akhirnya bermanfaat bagi pengembangan kompetensi peserta didik yang dimanfaatkan untuk persainngan global.

\section{Pendidikan Berbasis Kearifan Lokal Dalam Perspektif Global Dalam Menjaga Kelestarian Situs Ulak Lebar di Kota Lubuklinggau}

Model pendidikan berbasis kearifan lokal merupakan model pendidikan yang memiliki relevansi tinggi bagi pengembangan kecakapan hidup (life skills) dengan bertumpu pada pemberdayaan ketrampilan dan potensi lokal di masing-masing daerah, Dalam model pendidikan ini, materi pembelajaran harus memiliki makna dan relevansi tinggi terhadap pemberdayaan hidup mereka secara nyata, berdasarkan realitas yang mereka hadapi. Kurikulum yang harus disiapkan adalah kurikulum yang sesuai dengan kondisi lingkungan hidup, minat, dan kondisi psikis peserta didik juga harus memerhatikan kendalakendala sosiologis dan kultural yang mereka hadapi. Dalam pembelajaran, harus ditanamkan pada pikiran anakanak, bahwa manusia tidak sekedar hidup (to live), namun juga bereksistensi untuk berusaha mengatasi situasi serba terbatasnya (Nadlir, 2014: 306).

Lubuklinggau adalah kota setingkat Kabupaten paling Barat Propinsi Sumatera Selatan yang merupakan kota hasil pemekaran dari Kabupaten Musi Rawas. Pada tanggal 17 Oktober 2001 Kota Lubuklinggau diresmikan menjadi daerah otonom. Di Kota Lubuklinggau yang merupakan kota penghubung antara Propinsi Sumatera Selatan, Jambi dan Bengkulu, kota ini memiliki sejarah yang panjang. Salah satu peninggalan sejarahnya adalah sebuah situs sejarah yang jumlahnya ada 9 sektor, yaitu Situs Ulak Lebar. Dimana Situs Ulak Lebar merupakan situs sejarah yang berupa makam Islam di masa Kesultanan Palembang Darussalam yang berada di Kota Lubuklinggau. Perlu kita pahami, rangkaian masyarakat, adat istiadat dan budaya asli Kota Lubuklinggau semuanya berasal dari Situs Ulak Lebar.

Situs Ulak Lebar merupakan peninggalan bersejarah di Kota Lubuklinggau pada awal dan perkembangan Islam klasik di Lubuklinggau yang berada di pinggir Kota Lubuklinggau saat ini tepatnya di kaki Bukit Sulap Kelurahan Sidorejo 
Kecamatan Lubuklinggau Barat II. Perlu diketahui pada masa kekuasaan Hindia Belanda di Kesultanan Palembang tahun 1821, Belanda meneruskan sistem yang telah ada sejak masa kesultanan seperti sistem pemerintahan Marga. Marga Sindang Kelingi Ilir ini beribu kota di Lubuklinggau. Sebelumnya, Lubuklinggau hanyalah sebuah dusun kecil dengan masyarakatnya berasal dari Negeri Ulak Lebar. Mereka dipindahkan secara paksa oleh Pemerintah Hindia Belanda, mengingat lokasi Negeri Ulak Lebar yang tidak strategis untuk perkembangan pemerintah ke depan. Sistem pemerintahan Marga diatur dalam Undang-Undang Simbur Cahaya. Undang-undang ini pertama kali disusun di Istana Kesultanan Palembang tahun 1630 dan digunakan di seluruh wilayah Kesultanan Palembang sebagai hukum adat tertulis (Suwandi, 1996: 8).

Keadaan Situs Ulak Lebar saat ini, sebagian kurang terurus dengan baik. Banyak yang tertutupi oleh rumput dan tumbuhan liar sehingga beberapa sektor situs ini sulit untuk ditemukan oleh pengunjung. Begitu juga dengan sebagain aktivitas ekonomi masyarakat setempat, seperti penambangan atau pengerukan pasir dan batu di sekitar Situs Ulak Lebar juga rawan terhadap kerusakan situs. Masyarakat di sekitar situs belum begitu memahami tentang pentingnya arti situs tersebut bagi sejarah Lubuklinggau. Situs Ulak Lebar yang jumlahnya ada sembilan (9) sektor letaknya antar satu sama lain tidak berada dalam satu kompleks. Akses menuju situs Ulak Lebar juga belum memadai dan sebagian sektor tidak dapat dijangkau dengan kendaraan bermotor. Untuk itu pengabdian pada masyarakat mengenai arti penting situs Ulak Lebar ini sangat diperlukan dalam memberikan pemahaman kepada masyarakat khususnya terhadap generasi muda dan kalangan terpelajar, serta masyarakat luas secara umum.

Pendidikan berbasis kearifan lokal adalah pendidikan yang mengajarkan peserta didik untuk selalu dekat dengan situasi konkret yang mereka hadapi sehari-hari. Model pendidikan kearifan lokal merupakan sebuah contoh pendidikan yang mempunyai relevansi tinggi bagi kecakapan pengembangan hidup, dengan berpijak pada pemberdayaan keterampilan serta potensi pada setiap daerah. Pendidikan berbasis kearifan lokal dapat digunakan sebagai media untuk melestarikan potensi masing-masing daerah. Kearifan lokal harus dikembangkan dari potensi daerah. Potensi daerah merupakan potensi sumber daya spesifik yang dimiliki suatu daerah tertentu. Oleh karena itu, pendidikan harus sedapat mungkin memberikan independensi kepada peserta didik untuk menghargai dan mengembangkan potensinya. Mengenalkan kembali nilai-nilai kearifan lokal di Sekolah-Sekolah setidaknya dapat terus menguatkan budaya lokal agar tidak hilang dan ditinggalkan oleh masyarakat (Nadlir, 2014: 308).

Implementasi pendidikan berbasis kearifan lokal terhadap situs Ulak Lebar di Kota Lubuklinggau, antara lain melalui integrasi mata pelajaran dengan nilai karakter dalam pembelajaran dan teladan di lingkungan Sekolah dan sekitarnya. Manfaat dari pendidikan karakter berbasis kearifan lokal situs Ulak Lebar dapat memberikan pengalaman secara utuh dalam menanamkan, menumbuhkan, membangun, dan mengembangkan karakter atau kepribadian bangsa Indonesia yang berbudi luhur dan bermartabat, sebagai salah satu pembentuk identitas dan keterlibatan emosional masyarakat dalam 
menghayatan kearifan lokal yang kuat (Anggrayni, Novi Trisna, 2013: 5).

Sistem sosial terbangun dari hubungan antar manusia dan lingkungan tempat tinggal hidupnya. Penguasaan, pengelolaan dan pemanfaatan sumber daya lingkungan oleh manusia adalah sebuah interaksi dan adaptasi manusia dengan lingkungannya. Lingkungan akan berubah akibat perilaku manusia, tetapi lingkungan juga akan mempengaruhi perilaku manusia. Alam dapat hidup tanpa manusia, manusia tidak dapat hidup tanpa alam. Bentuk kearifan lokal akan lebih mudah diidentifikasi melalui proses pendidikan tentang sehari-hari yang dikembangkan oleh komunitas baik proses/cara/metodenya maupun isinya. Adat-istiadat, tembang, dogeng, permainan-permainan, teknik-teknik bercocok tanam, teknik mengolah hasil bumi, berbagai peraturan dan kesepatakan lokal, dan lain-lain merupakan salah satu wujud sistem pendidikan lokal (Nadlir, 2014: 304).

Pembelajaran berbasis kearifan lokal merupakan pembelajaran yang menempatkan siswa sebagai pusat pembelajaran student centered dari pada teacher centered. Belajar bukan sekedar kegiatan pasif menerima materi dari guru, melainkan proses aktif menggali pengalaman lama, mencari dan menemukan pengalaman baru serta mengasimilasi dan menghubungkan antara keduanya sehingga membentuk makna. Makna terlihat dari apa yang siswa lihat, dengar, rasakan, dan alami. Untuk guru, mengajar adalah kegiatan memfasilitasi siswa dalam mengkonstruksi sendiri pengetahuannya lewat keterlibatannya. Kearifan lokal yang terkandung dalam Situs Ulak Lebar memiliki fungsi pondamental, yaitu membentuk mental sosial dari komunitasnya. Oleh karenanya, nilai-nilai yang terkandung selalu digali dan diyakini memberikan sumbangan pada generasi muda. Hal ini yang memberikan dorongan kuat bagi para peneliti sejarah lokal untuk menyakinkan, bahwa nilai-nilai kearifan lokal Situs Ulak Lebar memiliki nilainilai historis dan norma-norma kebaikan dalam kehidupan masyarakat yang sangat perlu dilestarikan keberadaannya (Rosala, Dedi, 2016: 22).

\section{Kesimpulan}

Kesimpulan Di era globalisasi saat ini, dengan maraknya produksi budaya asing yang bebas masuk ke wilayah Indonesia dengan mudah mempengaruhi karakter anak bangsa, tentu perlu dicegah keberadaannya. Dunia pendidikan juga terkena dampak globalisasi, anak bangsa lebih suka yang instan, meninggalkan budaya lama yang dianggap sudah usang. Keinginan untuk belajar budaya sendiri sangat berkurang, padahal ciri khas bangsa Indonesia adalah keanekaragamannya di dunia. Karakter generasi muda yang sangat memprihatinkan tentunya membutuhkan sebuah perhatian yang lebih untuk mengurangi dampak negatif globalisasi. Untuk mengembangkan karakter anak bangsa tentunya membutuhkan perjuangan dan kerjasama yang lebih erat. Pengenalan budaya lokal bagi generasi muda sangat baik untuk mengenalkan sekaligus membentuk generasi muda lebih mencintai budaya bangsanya sendiri.

Pendidikan berbasis kearifan lokal dalam perspektif global, dapat menjadi sarana dalam penanaman dan implementasi karakter bangsa Indonesia yang baik dan benar dengan mendidik dan mengajarkan nilai-nilai kearifan lokal yang terdapat dalam Situs Ulak Lebar di Kota Lubuklinggau. Implementasi pendidikan berbasis 
kearifan lokal yang terdapat dalam Situs Ulak Lebar dapat diintegrasikan dalam mata pelajaran, kegiatan pembelajaran, dan teladan dalam kehidupan seharihari di lingkungan masyarakat luas. Pendidikan berbasis kearifan lokal Situs Ulak Lebar bermanfaat memberikan pengalaman secara utuh dalam menanamkan, menumbuhkan, membangun, dan mengembangkan karakter atau kepribadian bangsa Indonesia yang berbudi luhur dan bermartabat, sebagai salah satu pembentukan identitas, dan keterlibatan emosional masyarakat dalam penghayatan kearifan lokal yang terkandung dalam Situs Ulak Lebar.

\section{Daftar Referensi}

Arikunto, Suharsimi. 2002. Prosedur Penelitian (Suatu Pendekatan Praktek). Jakarta:Rineka Cipta.

Daryanto \& Rahardjo, Muljo, 2012. Model Pembelajaran Inovatif. Yogyakarta: Gava Media.

Chotib, 2006. Kewarganegaraan I: Menuju Masyarakat Madani. Jakarta: PT Ghalia Indonesia.

Koesoema A, Doni, 2015. Pendidikan Karakter di Zaman Keblinger. Jakarta: PT Gramedia Widiasarana Indonesia.

Lickona, T. 1992. Educating For Character How Our Schools Can Touch Respect and Respinsibility. New York-Toronto London-Sydney-Auckland: Bantam Books.

Muchtar, 2013. Metode Penelitian Deskriptif Kualitatif. Jakarta: GP Press Group.

Prawiradilaga, Dewi Salma, 2012. Wawasan Teknologi Pendidikan. Jakarta: Prenadamedia Group.
Sanjaya, Wina, 2016. Strategi Pembelajaran Berorientasi Standar Proses Pendidikan. Jakarta: Prenadamedia Group.

Sugiyono. 2015. Metode Penelitian Kuantitatif, Kualitatif, dan R \& D. Bandung: Alfabeta.

Suyatno, dkk, 2009. Pengembangan Profesionalisme Guru. Jakarta Selatan: Uhamka Press.

Suwandi, 1996. Laporan Kegiatan Survey Investigasi Cagar Budaya dan Budaya Benda Purbakala Daerah Tingkat I Musi Rawas Tahun Anggaran 1995/1996. Musi Rawas.

Jurnal:

Anggrayni, Novi Trisna, 2013.

Pendidikan Karakter Berbasis Kearifan Lokal Budaya

Jawa. Yogyakarta: PGSD Universitas PGRI.

Ghufronudin, dkk, 2017. Representasi Pendidikan Karakter Berbasis Kearifan Lokal Melalui Pembelajaran Membatik. Jurnal Analisis Sosiologi Volume 6 Nomor 2 Tahun 2017. UNS. Surakarta.

Haris, Abd. 2010. Strategi Pengembangan Perguruan Tinggi Islam Berbasis Kearifan Lokal di Tengah Tantangan Globalisasi, Makalah tidak Publikasi.

Kuntoro, Sodiq A, 2012. "Konsep Pendidikan Berbasis Kearifan Lokal sebagai Dasar Pembentukan Karakter Bangsa". Prosiding Seminar Nasional Ilmu Pendidikan. Program Studi Ilmu Pendidikan Program Pascasarjana Universitas Negeri Makasar. 
Nadlir, 2014. Urgensi Pembelajaran Berbasis Kearifan Lokal. Jurnal Pendidikan Islam Volume 02 Nomor 02 Tahun 2014. Jurusan Pendidikan Agama Islam. UIN Sunan Ampel. Surabaya.

Rosala, Dedi, 2016. Pembelajaran Seni Budaya Berbasis Kearifan Lokal Dalam Upaya Membangun Pendidika Karakter Siswa di Sekolah Dasar. Jurnal Pendidikan Seni Tari Volume 2 Nomor 1 Februari 2016. UPI. Bandung.

Rukiyati \& Purwastuti, L. Andriani, 2016. Model Pendidikan Karakter Berbasis Kearifan Lokal Pada Sekolah Dasar di Bantul Yogyakarta. Jurnal Pendidikan Karakter, Tahun VI, Nomor 1, April 2016. UNY.

Yogyakarta.

Widjajaputra, Bima. 2008.

Penyelenggaraan Pendidikan Berbasis Kearifan Lokal dan Hak-hak Anak Dalam Rambu-Rambu Pendidikan Berbasis Kearifan Lokal dan Hak-hak Anak. Yogyakarta: SD Sendangsari. 